DISCUSSION PAPER

\title{
IMPACTS OF THE EU ENLARGEMENTS ON THE NEW MEMBER STATES AGRICULTURE
}

\author{
Csaba Csaki $^{1}$, Attila Jambor $*^{1}$
}

Address: Csaba Csaki

${ }^{1}$ Corvinus University of Budapest, Department of Agricultural Economics and Rural Development, Fovam ter 8, 1093-Budapest, Hungary

*Corresponding author: attila.jambor@uni-corvinus.hu

\begin{abstract}
The paper provides descriptive analyses of the EU New Member States agriculture over the period from 2000 to 2011. In 2004 and 2007, twelve New Member States (NMS) joined the European Union, which has offered several possibilities and challenges to the newcomers. The aim of the paper is to discuss development of agriculture in the EU New Member States. We evaluate the status of this sector as well as identify factors lying behind the NMS performances. The EU accession has had an overall positive impact on the NMS agriculture, although the NMS capitalised their possibilities in a different manner, due to initial conditions and pre- and post-accession policies.
\end{abstract}

Keywords: EU enlargement, NMS agriculture, agricultural policy

JEL classifications: Q18 


\section{INTRODUCTION}

The enlargements in 2004 and 2007, when twelve New Member States (NMS) joined the European Union, caused several changes in agriculture. The aim of this discussion paper is to assess development of the New Member States agriculture, to evaluate the status of this sector and to identify factors lying behind different country performances. The paper is structured as follows. Section 2 analyses changes in agricultural performance after accession, followed by agricultural trade and price-income issues. Section 3 considers positive and negative effects of the EU accession, while Section 4 identifies agricultural policy factors lying behind different country performance. Section 5 concludes.

The paper provides descriptive analyses of the New Member States agriculture over the period from 2000 to 2011. Data from Eurostat, FAOStat, World Bank WDI and DG Agri were used.

\section{Changing agricultural performance}

The role of agriculture in a national economy is best characterised by the share of agriculture in GDP, which is shrinking all over the world. This tendency continued after accession in the NMS as well (table 1). The highest role of agriculture in GDP can be observed in Bulgaria (14\%), Romania (13\%) and Lithuania (6\%) in 2000, whereas other NMS countries had a share of 3-5\%. After the EU accession, shares in all cases decreased, though largest falls can be seen in countries with originally high values. In 2010, the share of agriculture in GDP was below $7 \%$ in all countries analysed (the majority was between 2-4\%) but we should note that it is consistently higher in all countries if food industry is taken into account. Note, that shares of individual NMS were still higher than EU27 average.

Development of agricultural output is another key indicator of assessing the EU enlargement impact. There are significant differences regarding the index of agricultural output in the NMS (table 2). It can be seen that Baltic countries and Poland increased gross agricultural output significantly in real terms over the period from 2000 to 2011. The agricultural output in real terms decreased or remained stable in all other countries concerned. Note, that the latter trend is valid for the EU old Member States (EU-15) as well as for the EU-27. The highest agricultural output increase is observable in the Baltic countries and Poland (approximately $+40 \%$ in a decade), while the largest decrease was in Bulgaria and Malta (around $-25 \%$ in a decade). Moreover, as a consequence of unfavourable weather 
conditions, agricultural output in 2009 was consistently lower than in 2006 in all countries but the Czech Republic and Malta.

Table 1 Share of agriculture in GDP in the NMS (\%)

\begin{tabular}{lrrrr}
\hline \hline Country & 2000 & 2003 & 2006 & 2010 \\
\hline \hline Bulgaria & 13.56 & 11.20 & 7.17 & 5.36 \\
Cyprus & 3.60 & 3.41 & 2.40 & $2.08^{*}$ \\
Czech Republic & 3.89 & 3.13 & 2.60 & 2.40 \\
Estonia & 4.82 & 3.99 & 3.21 & $2.86^{*}$ \\
Hungary & 5.40 & 4.30 & 4.01 & 3.53 \\
Latvia & 4.60 & 4.13 & 3.51 & 4.14 \\
Lithuania & 6.35 & 5.00 & 4.30 & 3.51 \\
Malta & 2.35 & 2.89 & 2.74 & $1.83^{* *}$ \\
Poland & 4.96 & 4.39 & 4.29 & 3.54 \\
Romania & 12.51 & 13.03 & 10.51 & 7.14 \\
Slovakia & 4.47 & 4.52 & 3.59 & 3.86 \\
Slovenia & 3.30 & 2.50 & 2.39 & 2.46 \\
EU27 & 2.31 & 2.03 & 1.65 & 1.48 \\
\hline \hline
\end{tabular}

Notes: * Data for $2008,{ }^{* *}$ data for 2009

Source: Own composition based on World Bank (2012).

Table 2 Index of agricultural output in real terms in the NMS $(2000=100)$

\begin{tabular}{lrrrr}
\hline \hline Country & 2000 & 2003 & 2006 & 2011 \\
\hline \hline Bulgaria & 84.30 & 78.24 & 69.98 & 74.76 \\
Cyprus** & 100.00 & 93.28 & 78.31 & 92.18 \\
Czech Republic & 83.58 & 87.18 & 90.97 & 94.21 \\
Estonia & 99.65 & 110.96 & 80.99 & 134.60 \\
Hungary & 86.54 & 88.29 & 79.63 & 100.87 \\
Latvia & 120.99 & 152.32 & 120.39 & 146.18 \\
Lithuania & 99.64 & 109.61 & 108.42 & 145.08 \\
Malta & 91.35 & 83.48 & 119.74 & 76.46 \\
Poland & 97.95 & 110.46 & 96.77 & 141.96 \\
Romania & 120.46 & 97.09 & 83.05 & 101.91 \\
Slovakia & 97.68 & 86.53 & 84.94 & 85.99 \\
Slovenia & 89.80 & 95.24 & 72.08 & 96.21 \\
EU15 & 95.79 & 86.84 & 85.77 & 95.97 \\
EU27 & 94.98 & 85.12 & 84.60 & 93.40 \\
\hline \hline
\end{tabular}

Notes: $*$ Estimated data, ${ }^{* *}$ For Cyprus, 2003=100

Source: Own composition based on Eurostat (2012).

Similar conclusions can be drawn if analysing agricultural output per hectare in the NMS after accession (figure 1). This indicator varied between 500-1000 EUR/ha in the years analysed. The highest values of agricultural output per hectare are observable in Slovenia (around 2000 EUR/ha), while lowest values show up for Latvia in all years analysed. Agricultural output per hectare in the NMS increased significantly after the EU enlargement. 
Hungary and Poland could reach the 1000 EUR/ha by 2011. Figure 1 presents the effects of climatic conditions and the economic crisis, showing consistently lower values for 2009. Note the gap between the EU15 and the NMS in land productivity. Only Slovenia reached the EU15 average.

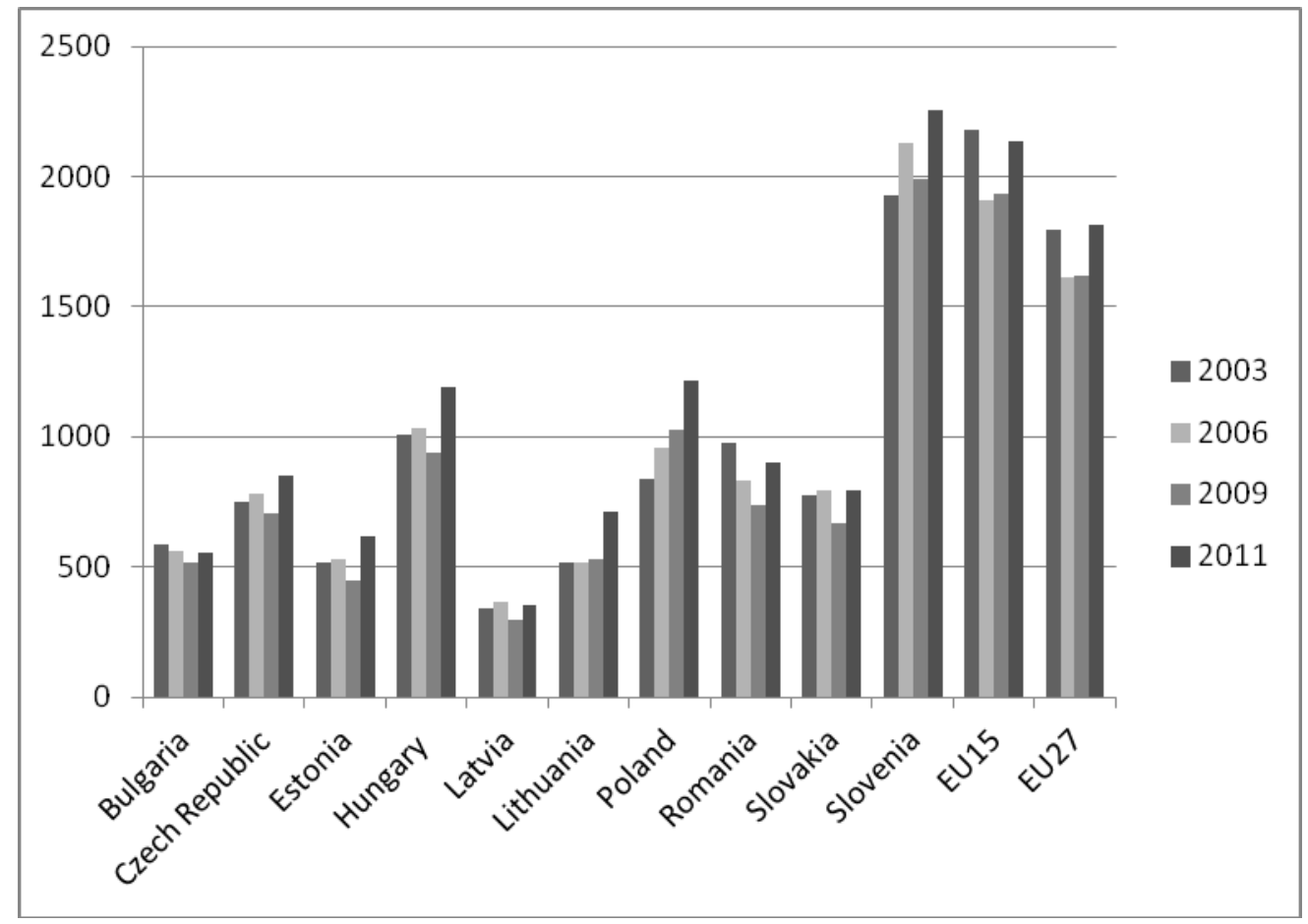

Figure 1 Agricultural output per hectare in real terms in the NMS (EUR/ha)* Notes: * Data for 2011 are based on estimations.

Source: Own composition based on Eurostat (2012) and FAO (2012).

Another measure closely linked to agricultural production performance is productivity. In 2010, the highest cereal yields (figure 2) was observed in Slovenia (5.97 tonnes/ha), while the lowest in Cyprus (1.60 tonnes/ha). After the EU accession, all NMS but Cyprus and Lithuania were able to increase their cereal yields. The Hungarian cereal yield growth was the highest (almost 60 per cent). The NMS however, still lags behind the EU-15 land productivity.

All NMS showed labour productivity increase after the accession, though a considerable 4-5 times lag still exists compared to the EU-15 (figure 3). In 2011, the highest agricultural output per annual work unit in real terms was in the Czech Republic (34,000 EUR/AWU), which is around EU-27 average, while the lowest was in Romania (6,000 EUR/AWU). 


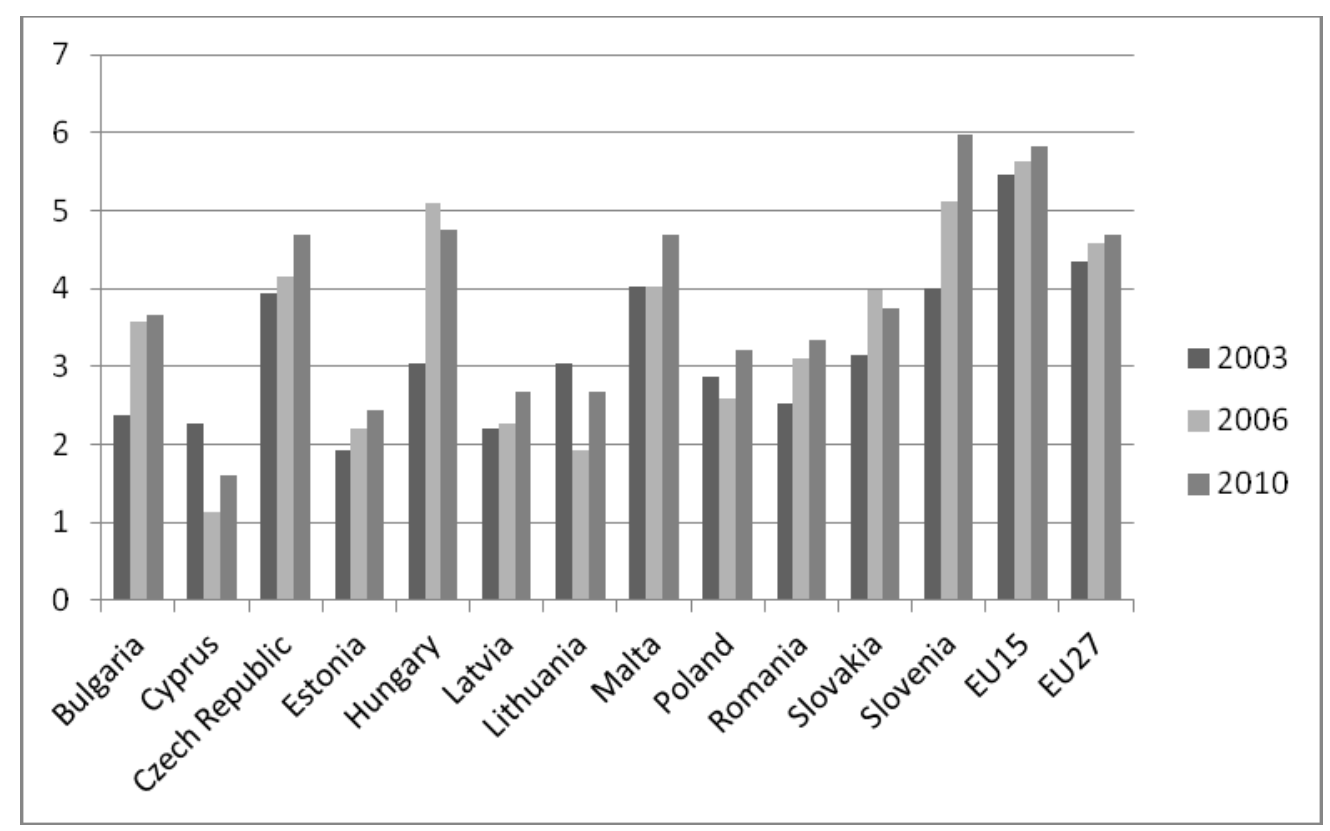

Figure 2 Yield of cereals in NMS (tonnes/ha)

Source: Own composition FAO (2012).

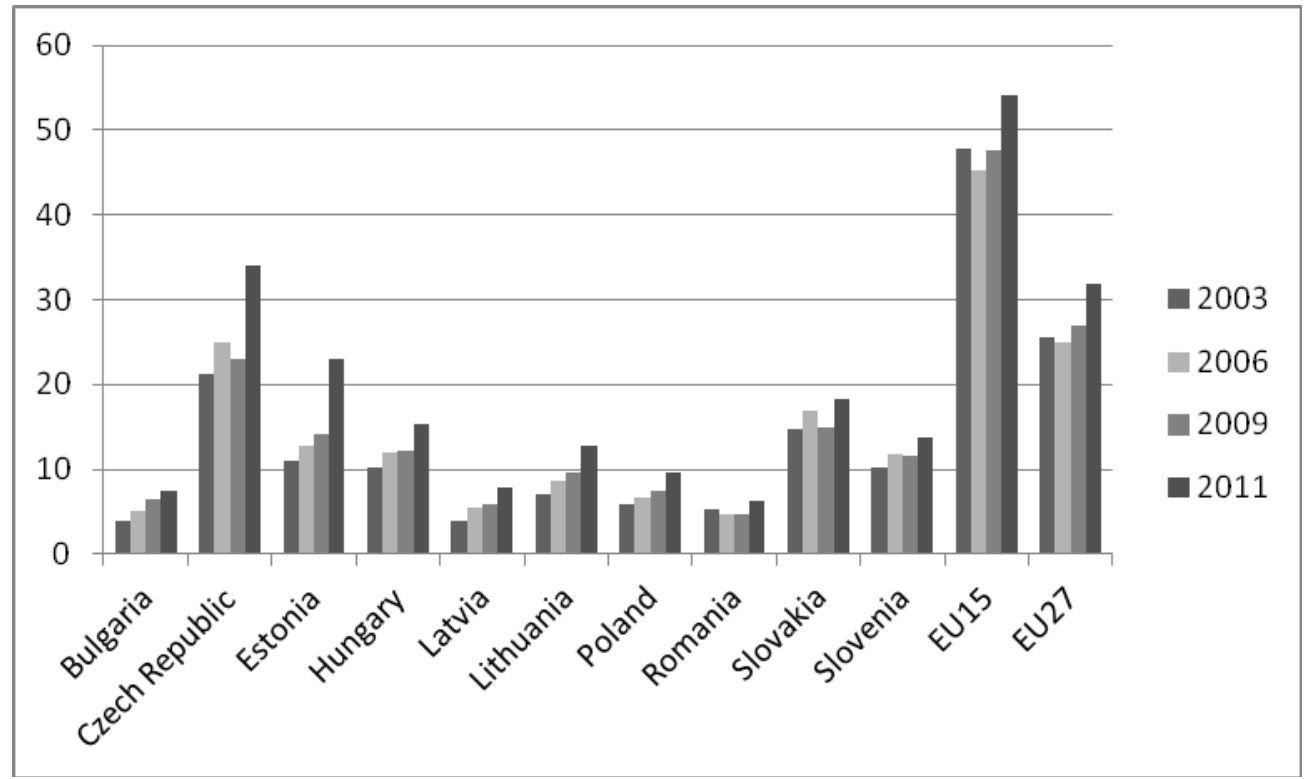

Figure 3 Agricultural output per annual work unit in real terms in the NMS (1000 EUR/AWU)

Notes: Data for 2011 are based on estimations.

Source: Own composition based on Eurostat (2012).

The EU enlargement has also affected the NMS structure of agricultural production (figure 4). It has moved after the accession towards a more extensive direction, namely towards crop production. In 2011, the share of crop output reached almost $75 \%$ of total 
agricultural output, while it was around $50-60 \%$ in the majority of the cases. Such a change was mainly due to the grain intervention system of the Common Agricultural Policy (CAP) and increasing feed prices in the region.

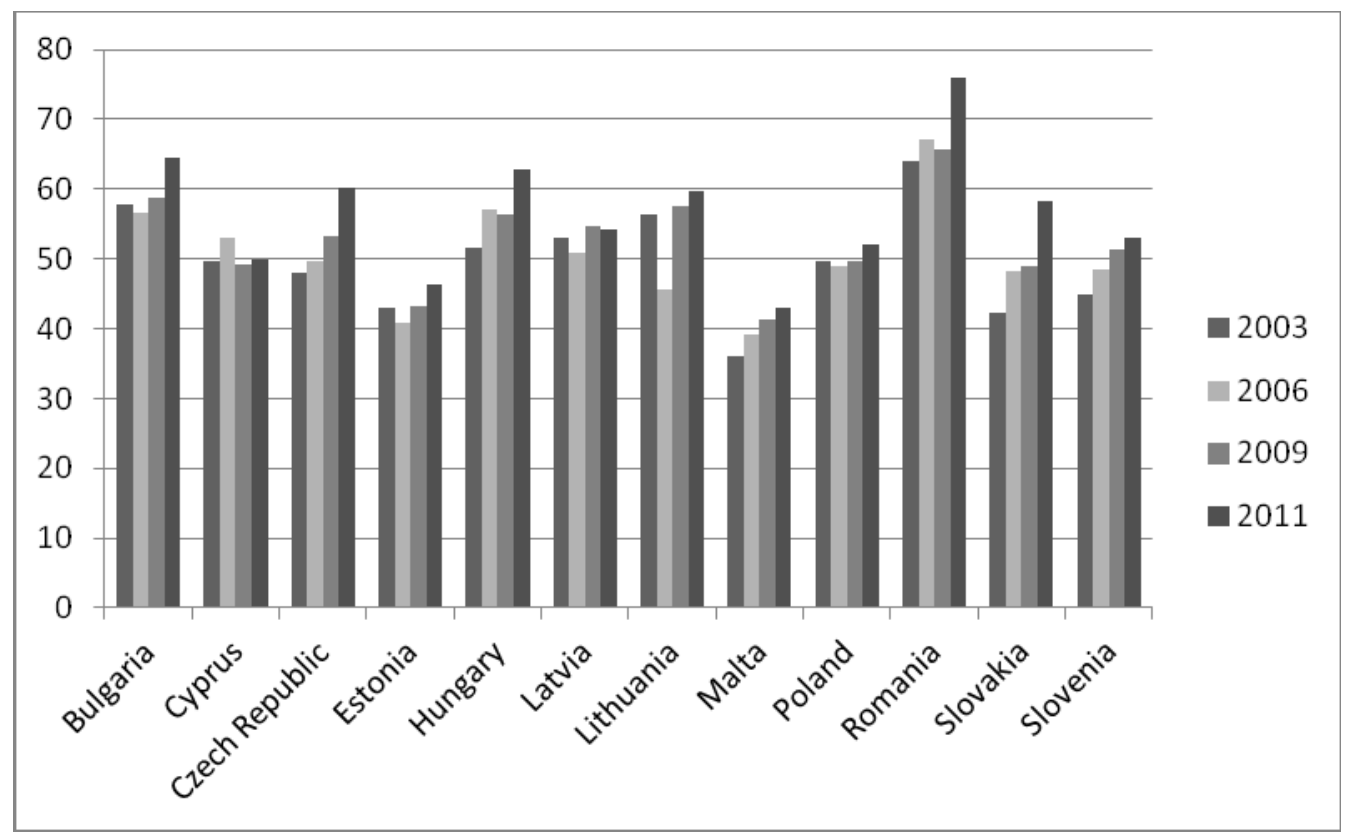

Figure 4 Rate of crop output in total agricultural output (\%)

Notes: Data for 2011 are based on estimations.

Source: Own composition based on Eurostat (2012).

The EU accession has had a considerable impact on agricultural performance of the NMS. The role of agriculture has decreased; agricultural output has changed to a limited extent. Productivity lag decreased, but still remained significant. Moreover, the accession has made the NMS agricultural production structure more extensive.

\section{Increased agri-food trade}

The accession had a significant impact on the NMS agri-food trade. First of all, the value of agri-food trade has measurably increased in nominal terms after 2004 (table 3). The agri-food export of Hungary doubled from 2003 to 2011, while that of Latvia and Romania increased almost six times. At the same time, agri-food import tripled in the majority of the cases. The biggest increase was observed in Latvia for export and in Slovakia for import, while the smallest increase in agri-food trade was in Malta. Note that export growth was faster than import growth in most cases. 
Agri-food trade growth in nominal terms however, has not resulted in an improvement of agri-food trade balance in most cases (figure 5). Only Bulgaria, Hungary, Lithuania and Poland showed a positive agri-food trade balance in the period analysed. The Polish balance exceeded 2.5 billion EUR and the Hungarian almost reached 2 billion EUR in 2011. The accession has further deteriorated agri-food trade balance in the majority of the NMS. The biggest deficit was observed in the Czech Republic and Romania (around 1.5 billion EUR in 2011).

Table 3 Changes in the NMS agri-food trade in nominal terms (2003=100)

\begin{tabular}{lrrrrrr}
\hline \hline \multirow{2}{*}{ Country } & \multicolumn{3}{c}{ Export } & \multicolumn{3}{c}{ Import } \\
\cline { 2 - 7 } & 2006 & 2009 & 2011 & 2006 & 2009 & 2011 \\
\hline \hline Bulgaria & 158 & 281 & 465 & 172 & 322 & 429 \\
Cyprus & 127 & 124 & 164 & 159 & 201 & 220 \\
Czech Republic & 189 & 245 & 310 & 173 & 224 & 278 \\
Estonia & 179 & 214 & 336 & 152 & 182 & 239 \\
Hungary & 128 & 164 & 225 & 205 & 244 & 310 \\
Latvia & 275 & 414 & 650 & 178 & 229 & 304 \\
Lithuania & 233 & 359 & 514 & 207 & 284 & 411 \\
Malta & 157 & 87 & 158 & 123 & 142 & 152 \\
Poland & 212 & 268 & 351 & 188 & 271 & 362 \\
Romania & 172 & 341 & 618 & 159 & 250 & 290 \\
Slovakia & 258 & 329 & 477 & 224 & 338 & 433 \\
Slovenia & 147 & 194 & 279 & 168 & 230 & 290 \\
\hline \hline Source: Ownyyyyyy
\end{tabular}

Source: Own composition based on Eurostat (2012).

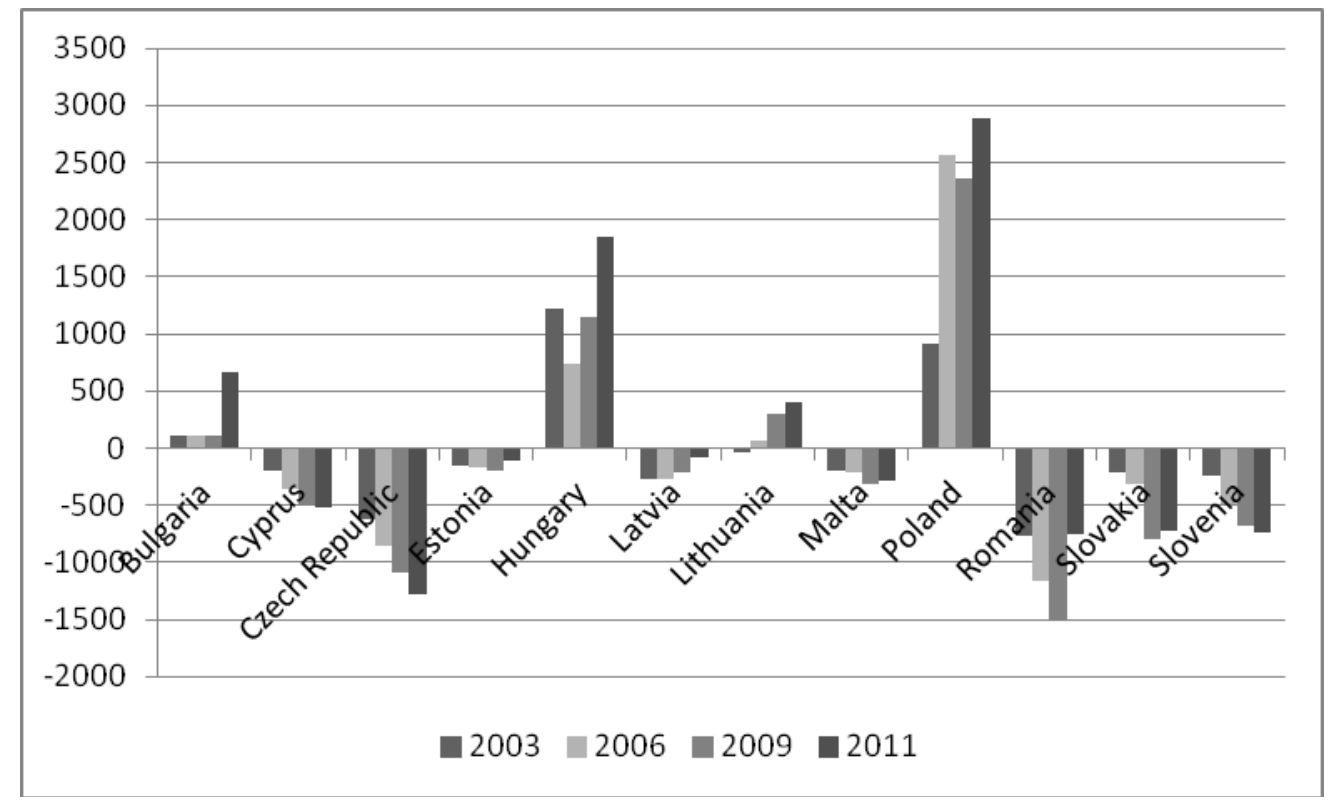

Figure 5 Agri-food trade balance in the NMS (million EUR)

Source: Own composition based on Eurostat (2012). 
The NMS performances are based on different product structure (table 4). The share of raw materials in agri-food export has increased in all NMS, but Cyprus, Poland and Romania. The processed products share in the NMS agri-food import has also increased, except for Latvia, Lithuania, Malta and Slovakia. These changes clearly refer to a deteriorating agri-food trade structure in the region. The biggest raw material oriented agri-food exporter was Romania, while Malta imported the most processed agri-food products.

Table 4 Share of raw materials and processed products in the NMS agri-food trade (\%)

\begin{tabular}{lrrrrrrrr}
\hline \hline \multirow{2}{*}{ Country } & \multicolumn{3}{c}{ Export } & \multicolumn{5}{c}{ Import } \\
\cline { 2 - 9 } & 2003 & 2006 & 2009 & 2011 & 2003 & 2006 & 2009 & 2011 \\
\hline \hline Bulgaria & 39 & 45 & 50 & 57 & 76 & 80 & 77 & 78 \\
Cyprus & 56 & 57 & 50 & 51 & 73 & 73 & 75 & 75 \\
Czech Republic & 22 & 32 & 36 & 35 & 67 & 71 & 75 & 74 \\
Estonia & 12 & 20 & 20 & 29 & 77 & 79 & 81 & 78 \\
Hungary & 33 & 34 & 38 & 35 & 72 & 73 & 75 & 76 \\
Latvia & 18 & 23 & 43 & 35 & 75 & 75 & 71 & 72 \\
Lithuania & 33 & 34 & 43 & 43 & 71 & 67 & 64 & 56 \\
Malta & 10 & 28 & 21 & 29 & 81 & 76 & 81 & 81 \\
Poland & 28 & 24 & 25 & 20 & 62 & 66 & 68 & 67 \\
Romania & 67 & 68 & 68 & 61 & 60 & 79 & 74 & 70 \\
Slovakia & 26 & 32 & 36 & 35 & 75 & 73 & 77 & 75 \\
Slovenia & 13 & 34 & 44 & 48 & 70 & 68 & 68 & 65 \\
\hline \hline
\end{tabular}

Source: Own composition based on Eurostat (2012).

While the MNS performances have differed significantly, both export and import have increased in the region in nominal terms. The largest agri-food exporters in the region were Poland and Hungary. The eight NMS countries have experienced an increasing deficit. Moreover, there was a high and increasing share of raw materials in the NMS agri-food export with a same tendency in majority of the NMS agri-food imports of processed products. Poland had a remarkable success in its agricultural trade performance after the accession. Its position has changed from an agricultural importer to the largest exporter in a region in the observed period.

\section{Increasing prices and incomes}

The EU accession had a significant impact on agricultural prices and incomes. Agricultural raw material prices have shown a remarkable increase for a few years. Wheat producer prices in the NMS (figure 6) have followed the EU respective average prices to a great extent. They increased by roughly 2.5 times to 2008 compared to 2000. Initial decline of general price 
trends on world agricultural product markets was followed by another price hike in 2011 (FAO 2011), which was also valid for the NMS.

Similarly to wheat, fresh cow milk producer prices have also shown a significant increase during the past few years (figure 7). They varied to a great extent country by country and ranged between 207 USD (Lithuania) and 635 USD (Romania) per tonnes in 2009. Compared to 2000, milk producer prices have increased by $50-80 \%$ in the NMS except for Bulgaria and Romania, where the growth was two and five times higher. The NMS milk producer prices were generally below the EU-15 prices, apart from Romania. Note that the largest price adjustment occurred where the pre-accession producer prices were lower.

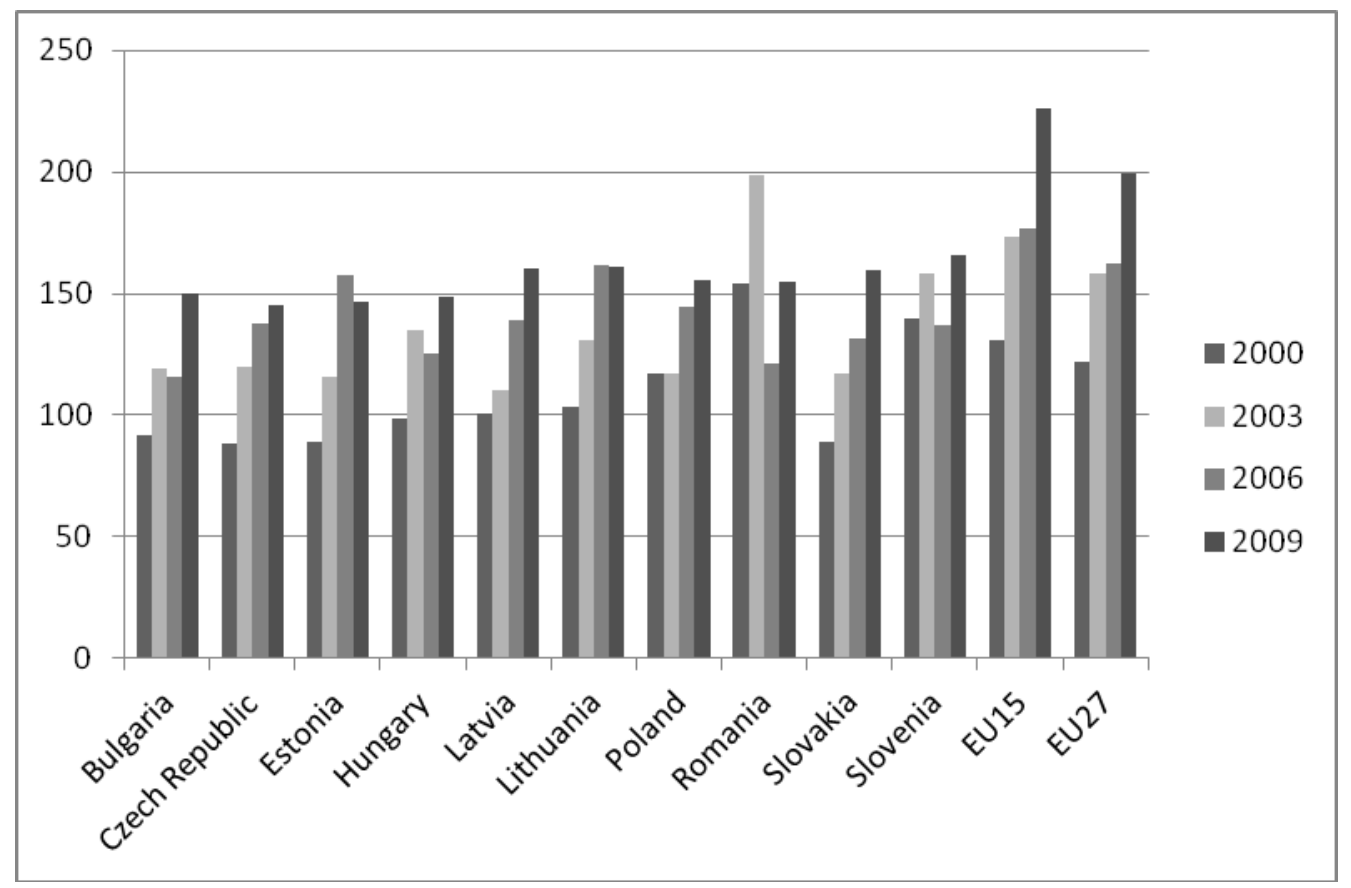

Figure 6 Agri-food trade balance in the NMS (million EUR)

Source: Own composition based on FAO (2012).

Increasing producer prices have also resulted in an increase in producer incomes in the NMS after the accession. Real farm income per annual work unit (AWU) has grown in all NMS in the region from 2003 to 2011, though to a different extent (figure 8). The biggest increase was observed in Estonia (almost three times), while the smallest in Romania (almost stagnation). The EU average farm incomes have hardly changed in the observed period and thereby agricultural income adjustment, similarly to price adjustment, has begun between the old and the new MS. 


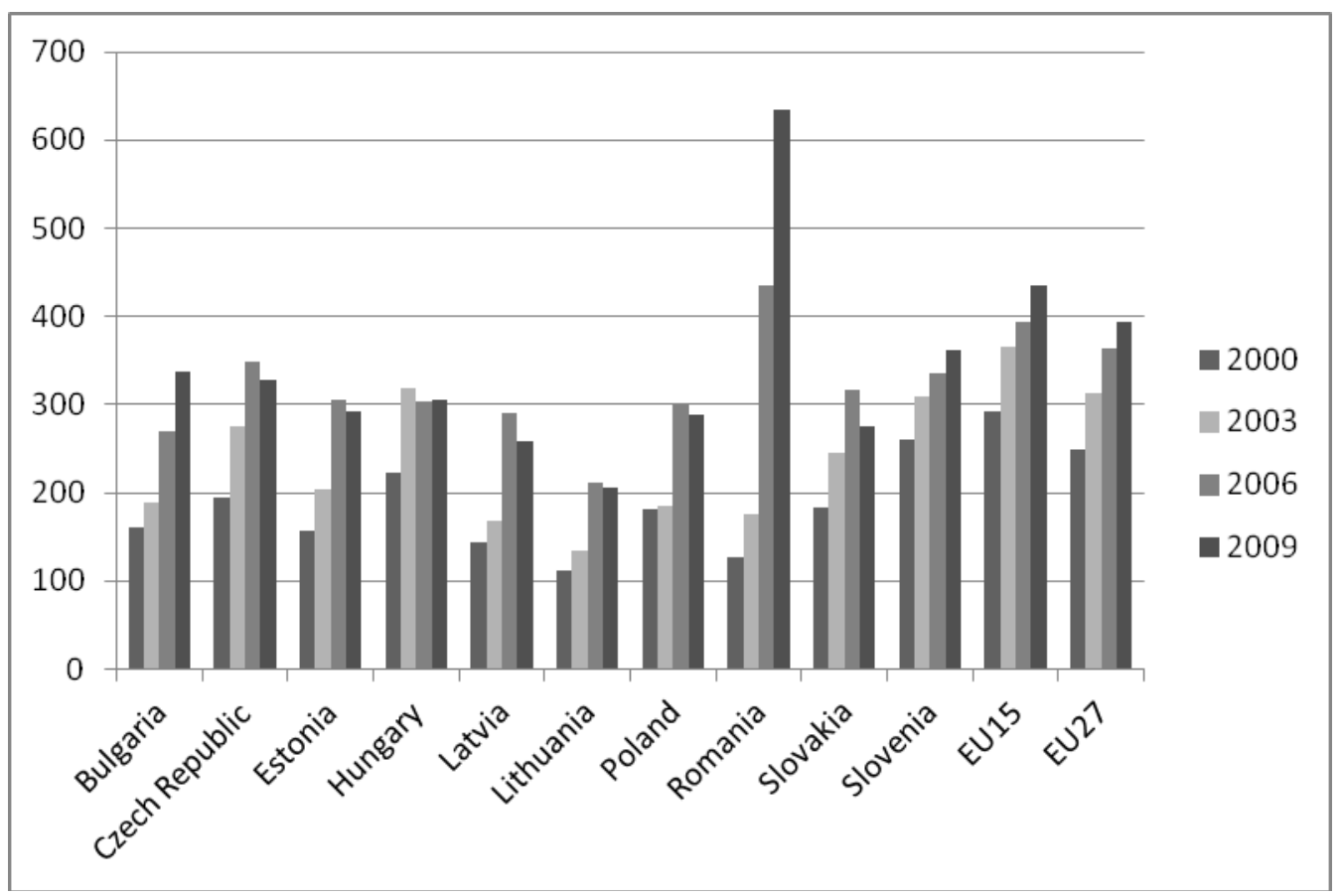

Figure 7 Agri-food trade balance in the NMS (million EUR)

Source: Own composition based on FAO (2012).

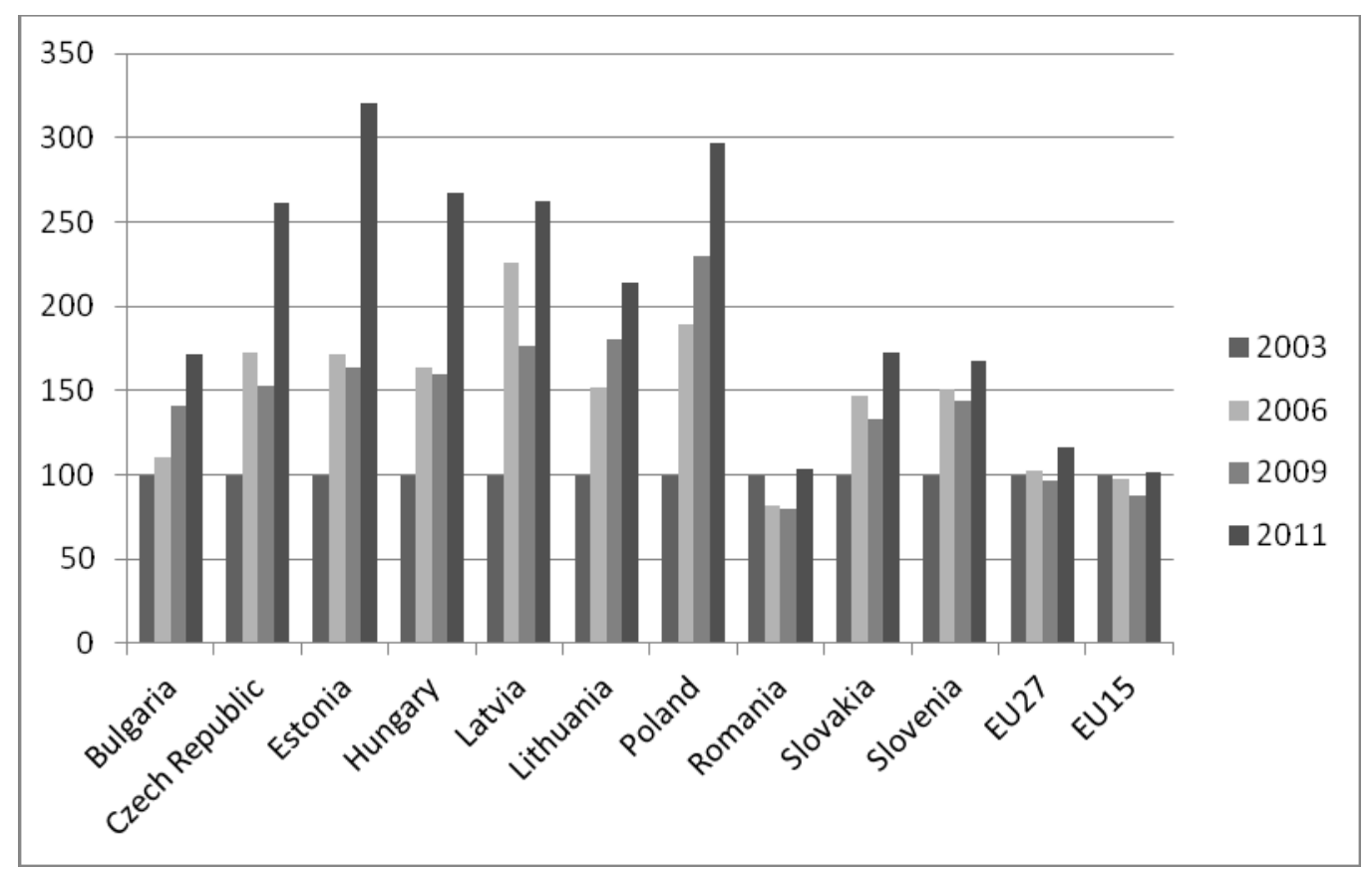

Figure 8 Index of real farm income per annual work unit in the NMS (2003=100) Source: Own composition based on Eurostat (2012).

A significant increase has occurred in the NMS agricultural producer prices in nominal terms, while real producer prices have still remained below the EU-15 levels. Price adjustment was larger in countries with lower pre-accession levels. There has been a 
significant increase of farming incomes in the NMS, mainly due to agricultural subsidies, while initial differences have remained among countries.

\section{Positive and negative agricultural effects of accession}

The EU accession had an overall positive impact on the NMS agriculture. The enlarged EU market, containing around half a billion people, offers tremendous opportunities for their agricultural sectors. The NMS farmers' incomes have increased after the accession. The accession has provided a solid and uniform policy and institutional framework under which national agricultural policies are implemented.

Besides these benefits however, several difficulties of the EU membership have emerged. First of all, the accession has made the NMS part of a large, rather competitive market, where they have limited potential to withhold competitive pressure. This situation is due to rapid emergence of vertically coordinated food chains, including hypermarkets, supermarkets and multinational agro-processing companies with regional procurement systems, thus creating new and much more competitive conditions for producers and consumers. The market share of foreign-origin products has increased significantly, while domestically produced products have to compete with the free flow of foreign produce. Due to very strong price competition, consumers are generally the beneficiaries of these changes. At the same time producers are not always able to adjust, or to cope with business practices employed by the large chains. The concentrated and Europe-wide procurement systems of the major chains create high requirements for suppliers and impose strong price pressures as well. Farmers' adjustment to the enlarged integrated food markets is one of the most pressing demands of the post accession situation and requires public involvements (Csaki and Jambor, 2010).

The evolving food crisis has also resulted in several difficulties. High prices of agricultural raw materials and energy, in addition to the obligatory EU standards after accession, have all made the manufacture of processed products more expensive. These additional costs are difficult to pass on to consumers due to the fierce price competition. As a result, the regional food industry has found itself under extreme pressure, from which it still has not recovered.

The subsidy policy of competitors is also a source of concern. Traditionally high agricultural subsidies in the EU-15 have artificially increased the competitiveness of agri-food products imported by the NMS, generating unequal competitive market positions on the EU-27 markets (Ciaian et al., 2010). This argument is strengthened if account is taken of the 
small proportion of direct payments that have been received by the NMS immediately after the accession. Moreover, adjustment to the EU subsidy levels, coupled with gaining acquaintance of the new system and creation of necessary institutional infrastructure, have been time consuming. Thus the NMS delayed their responses to address its competitive disadvantages.

The handicap of small farmers also raises serious problems. As discussed earlier, one of the major characteristics of the NMS agriculture is diversity of farming structures. This diversity means that large, as well as small farms exist in national agricultures at the same time, differing in terms of both, attitudes towards commercialisation and factual circumstances. The large number of subsistence and semi-subsistence farms is a special characteristic of the NMS. These farms are fundamentally different from small farms in the EU15. It appears that subsistence and semi-subsistence farms are handicapped in many ways. Agricultural policies before the accession neglected these farms. Similarly, the CAP provides insufficient support for them. As a result, agricultural incomes of small farms fail to provide them with an acceptable level of living in most cases. The majority of small farms hardly have any relationship with national or regional markets, making it difficult for them to sell their produce. Since there are limited job opportunities outside of agriculture in rural areas, family members are often forced to leave rural areas permanently. Specific policies are needed for managing this problem including policy actions focused on small farms (Csaki and Jambor, 2010).

Moreover, one of the major problems of the NMS accession was the widening urbanrural income gap. Rural population and rural areas have been lagging behind since the beginning of transition period in the early 90s, and this has not been yet solved by the accession.

The "one size fits all” approach of the CAP does not work as it fails to recognise the structural diversity of individual Member States. More targeted and locally adjusted agricultural policy programmes are needed in the future.

The EU accession had an overall positive impact to regional agriculture, though individual country performances have significantly differed. These differences have evolved due to a number of reasons.

\section{Initial conditions}

The first reason behind the NMS different performances lies in the initial conditions. Different distribution of agricultural land quality and quantity, together with differences in 
agricultural labour and capital endowment, definitely had an impact. Poland and Romania had the biggest areas of agricultural land and number of labour among the NMS, while the largest capital endowment could be found in Slovenia.

Another important difference lies in farm structures. Poland and Slovenia are characterised by small scale agriculture which proves to be beneficial. Due to complex process of land privatisation and farm restructuring, farm structures in other NMS were both ends of ‘dual’ farming system. Small farms are generally too small, farmers are inexperienced and suffer from a lack of resources; while large farms have some heritage of collective farming system with some embedded inefficiencies. One of the characteristics of the NMS region is high, but decreasing, number of small farms.

Besides these factors, national agricultural policy and institutional framework basically determine individual country performances.

\section{Impacts of pre-accession policies}

The post-accession performance of the NMS has been influenced strongly by the agricultural policy framework prevailing in the individual countries during the pre-accession period especially from 1998 to 2004. The candidate countries implemented quite different policies, some with positive, and others with negative impacts after the accession.

Measures in favour of competitiveness enhancement have definitely proven to be beneficial. The NMS where agricultural subsidies to farmers remained at a low level (e.g. Poland) have gained. The accession has provided visible incentives for production and led to an increase of agri-food trade balance. Those NMS providing initially high and uneven price and market support (e.g. Hungary, Romania) are considered to lose with accession as it has brought hardly any price increase. Agricultural policy not in favour of measures aiming to enhance competitiveness was a failure, resulting in a situation where the majority of farmers were not prepared for the accession (Swinnen and Rozelle, 2006).

Differently implemented land and farm consolidation policies have also had diverse effects on post-accession country performance. Restrictive pre-accession land policies and the lack of land and farm consolidation (e.g. in Hungary) has negatively influenced the capacity to take advantage of the enlarged markets by constraining significantly the flow of outside capital to the agricultural sector (Ciaian et al., 2010). Conversely, liberal land policies (e.g. in Baltic countries) helped the agricultural sector to obtain more resources and utilise better the possibilities created by the accession. 
The ways in which the NMS used EU-funded pre-accession programmes such as SAPARD, ISPA and PHARE was also important. Those who focused on competitiveness enhancement and production improvement were better placed to realise the post- accession benefits. On the contrary, delays in creating required institutions, as well as the initial disturbances of implementation, resulted in the loss of some EU funds in a number of countries (Swinnen and Rozelle, 2006).

\section{Impacts of post-accession policies}

Individual NMS performances were affected by policies implemented after 2004 and 2007. One of the most important was introduction of the CAP. According to the Copenhagen agreement, the NMS could choose between a simplified area-based payment system (SAPS) complemented with additional support for rural development; and implementation of the EU15 type CAP. All NMS, except Slovenia and Malta, opted for the simplified payment system, whereby the direct payment was 25 per cent of the EU-15 level in 2004. The NMS had the freedom to top up the direct payments initially to 25 per cent of the EU-15 level. They could transfer part of the rural development support to the direct payment or use national funds (initially a maximum of 30 per cent above the set EU level); all of the NMS used this latter opportunity but to different degrees. Despite the fact that the NMS were not eligible for the total payments of the EU-15, the CAP has significantly increased farmers' incomes (figure 8).

It is important to note, that the level of support was set on the basis of the yields in the pre-accession period, causing a huge diversity in distribution of direct payments at the European level. Direct payments varied between 100 EUR and 800 EUR per hectare and between 1000 EUR and 40000 EUR per beneficiary in 2008 in the EU-27. The average EU levels of direct payments were $300 \mathrm{EUR} / \mathrm{ha}$ and around $6000 \mathrm{EUR} / \mathrm{farm}$, while the respective average values for the NMS were 200 EUR/ha and approximately 2500 EUR/farm (DG Agri, 2011). These differences have had a significant impact on country performances in the NMS after the accession.

The most NMS give priority to the CAP second pillar, while the EU-15 countries mainly focus on the first pillar. Inside rural development, the biggest support goes to enhancement of competitiveness and to agri-environmental measures (DG Agri, 2011).

The grain market intervention system of the CAP was important post-accession policy introduced. The intervention system helped to ease crop farmers' problems and provided them significant income. It stabilised grain-feed prices on a significantly higher level, than it was prior to the accession, and resulting in significant difficulties for the livestock sector. 
The Common Agricultural Policy has brought safety for the NMS agriculture. During the economic crisis, the NMS national budgets are under pressure and might not be able to appropriately subsidise agriculture and ease the crisis impacts.

\section{CONCLUSION}

The NMS accession to the EU has had a significant impact on the NMS agricultural performance. The role of agriculture has further decreased in the NMS economies; productivity lag has decreased, but remained remarkable. Furthermore, the accession has strengthened extensive ways of production. The NMS agri-food export and import have increased in the region in nominal terms, while country performances have differed significantly. The biggest NMS agri-food exporters were Poland and Hungary. The remaining eight NMS have experienced an increasing trade deficit after 2004. There was a high and increasing share of raw materials in the NMS agri-food export. The same tendency was observed in majority of the NMS agri-food imports of processed products. After the accession a significant increase of the NMS agricultural producer prices in nominal terms has occurred, while real producer prices have still remained below the EU-15 levels. Price adjustment was larger in the NMS with lower pre-accession levels. There has been a significant increase of farming incomes in the NMS, mainly due to agricultural subsidies. Initial differences among countries however, have remained.

The enlarged EU market, containing around half a billion people, offers tremendous opportunities for the NMS agricultural sectors. The EU accession has increased farmers' incomes, as well as provided a solid and uniform policy and institutional framework, under which national agricultural policies are implemented. Several difficulties have also emerged after the accession e.g. a limited potential to withhold competitive pressures; a lack of harmonised support levels; a handicap of small farmers and rural-urban income gap.

The NMS have significantly differed in utilising possibilities of the EU enlarged market, mainly due to initial conditions, pre-accession and post-accession policies. From the initial conditions mainly different distribution of agricultural land quality and quantity and differences in agricultural labour and capital endowment have to be mentioned. The most important pre-accession policies were measures in favour of enhancement of competitiveness, liberal land and farm consolidation policies and efficiently used pre-accession funds. The uniform policy framework, different levels of national support and the impact of macro policies had the most important impact on the NMS agriculture after the accession. 
Acknowledgments: The authors gratefully acknowledge financial support from the Hungarian Scientific Research Fund No. 83119 “Changes and determinants of Central and Eastern European agricultural trade”.

\section{REFERENCES}

CSÁKI, CS. - JÁMBOR, A. 2010. Five Years of Accession: Impacts on Agriculture in the NMS. In EuroChoices, ISSN 1746-692X, 9, (2) 10-17.

CSÁKI, CS. - JÁMBOR, A. 2009. The Diversity of Effects of EU Membership on Agriculture in New Member States. FAO Regional Office for Europe and Central Asia, Policy Studies on Rural Transition, No. 2009-4.

CIAIAN, P., KANCS, D’ARTIS AND SWINNEN, J.F.M. 2010. EU land markets and the Common Agricultural Policy. In Agricultural and Rural Policy, 2010..

DG AGRI. 2011. The future of CAP direct payments. Available: http://ec.europa.eu/agriculture/publi/app-briefs/02_en.pdf

EUROSTAT. 2012. http://epp.eurostat.ec.europa.eu/portal/page/portal/statistics/themes

FAO. 2012. http://faostat.fao.org/site/339/default.aspx

FAO. 2011. Price Volatility in Food and Agricultural Markets: Policy Responses. Policy Report.

SWINNEN, J.F.M. AND ROZELLE, S. 2006. From Marx and Mao to the Market: The Economics and Politics of Agricultural Transition.UK: Oxford University Press, 2006. 240 p. ISBN 0199288917.

WORLD BANK. 2012. http://databank.worldbank.org/ddp/home.do?Step=12\&id=4\&CNO=2 